УДК 811.133.1'373.612.2:32](045)

DOI https://doi.org/10.26661/2414-9594-2020-2-3

\title{
МАНІПУЛЯТИВНИЙ ПОТЕНЦІАЛ ПОЛІТИЧНОЇ МЕТАФОРИ У ПРОМОВАХ СУЧАСНИХ ФРАНЦУЗЬКИХ ПОЛІТИКІВ
}

\author{
Буць Ж. В. \\ кандидат філологічних наук, дочент, \\ доиент кафедри теорії, практики та перекладу франиузької мови \\ Національний технічний університет Украӥни \\ «Київький політехнічний інститут імені Ігоря Сікорського» \\ пр. Перемоги, 37, Київ, Украӥна \\ orcid.org/0000-0002-5938-2694 \\ jeannette@ukr.net
}

Седляр А. В.

студентка магістратури кафедри теорії, практики та перекладу франиузької мови

Національний технічний університет України

«Київський політехнічний інститут імені Ігоря Сікорського»

пр. Перемоги, 37, Київ, Украӥна

orcid.org/0000-0001-8931-0715

anny.sdlr@gmail.com

Ключові слова: маніпуляція, політична метафора,

політичний дискурс, промова, художній засіб.
У статті досліджуються актуальні питання метафоризації політичних текстів. Найбільш маніпулятивно спрямованими є промови, оскільки вони готуються завчасно, мають чітку ціль виголошення та відрізняються прямим контактом з аудиторією. Саме вони стали об'єктом нашої роботи. Наше дослідження націлене на розширення знань про маніпулятивну спрямованість метафоричних конструкцій у політичному дискурсі та розкриття інтенцій автора тексту, прихованих для загального адресата. Розглянуто промови сучасних французьких політиків на предмет наявності у них метафоричних конструкцій, метою яких $є$ маніпуляція. Проаналізовано різні типи метафор: фізіологічна, кримінальна, театральна, мілітарна метафори, метафора шляху та засобів пересування, природної стихії та будинку. Виявлено значення кожного прикладу та виокремлено функції цього художнього засобу. Проаналізовано той факт, що порівняння політичних реалій з об'єктами повсякденного життя людини допомагає останній краще осягнути інформацію, яку транслює оратор.

3'ясовано, що за допомогою політичної метафори оратори можуть впливати на емоції, вибір та дії аудиторії. Це є засобом агітації, пропаганди та навішування опозиції «корисно-шкідливо». Доведено, що підміною політичних реалій на образи інших сфер життя можна демонізувати або ідеалізувати будь-яку ситуацію чи особу. Досліджено поняття «апперцепція», яке визначаємо як залежність сприйняття людиною певної інформації та об'єктів реального світу від ії попереднього досвіду. Проведено паралель між сприйняттям метафоричного образу та отриманим життєвим досвідом людини. Аргументовано факт того, що метафору необхідно розглядати не лише як метод прикрашання текстів, а й як один із потужних засобів впливу на емоції та почуття аудиторії. Обгрунтування такого аспекту використання художнього засобу є важливим елементом у вивченні маніпулятивних технік політичного дискурсу. 


\title{
MANIPULATIVE POTENTIAL OF POLITICAL METAPHOR IN THE SPEECHES OF MODERN FRENCH POLITICIANS
}

\author{
Buts Z. V. \\ Ph.D. in Philology, Associate Professor, \\ Associate Professor at the Department of Theory, Practice and Translation of the French Language \\ National Technical University of Ukraine "Igor Sikorsky Kyiv Polytechnic Institute" \\ Peremohy ave., 37, Kyiv, Ukraine \\ orcid.org/0000-0002-5938-2694 \\ jeannette@ukr.net \\ Sedliar A. V. \\ Master's Student at the Department of Theory, Practice and Translation of the French Language \\ National Technical University of Ukraine "Igor Sikorsky Kyiv Polytechnic Institute" \\ Peremohy ave., 37, Kyiv, Ukraine \\ orcid.org/0000-0001-8931-0715 \\ anny.sdlr@gmail.com
}

Key words: manipulation, political metaphor, political discourse, speech, figure of speech.
The article examines current issues of the metaphorization of political texts. Speeches are the most manipulative, because they are prepared in advance, have a clear purpose of utterance and are in direct contact with the audience. They are the object of our work.

The research aims to expand knowledge about the manipulative potential of metaphorical constructions in political discourse and to reveal the intentions of the author of the text, hidden from the average recipient.

There have been considered the speeches of modern French politicians on the presence of metaphorical constructions aimed at manipulation. Different types of metaphors are analyzed: physiological, criminal, theatrical, military metaphors and others. The meaning of each example and the functions of this figure of speech are revealed. It has been analyzed that comparing political realities with objects of everyday life helps a person to better understand the information transmitted by the speaker.

It has been found that speakers can influence the emotions, choices and actions of the audience by applying a political metaphor. It is a means of agitation, propaganda and labeling "good or bad". It has been proved that substituting political realities for images of other spheres of life can demonize or idealize any situation or person. It has been investigated the concept of apperception which is defined as the dependence of a person's perception of certain information and objects of the real world on his previous experience. A parallel is drawn between the perception of a metaphorical image and the received life experience of a person. It is argued that metaphor should be considered not only as a method of embellishing texts, but also as one of the powerful means of influencing the emotions and feelings of the audience. This aspect of the use of figure of speech is an important element in the study of manipulative techniques of political discourse.
Постановка проблеми. У сучасному світі, переповненому інформацією, дуже важливо вміти розрізняти маніпуляцію, яка досить часто $\epsilon$ непомітною для середньостатистичного адресата повідомлення. Тактики впливу поширені у багатьох галузях нашого життя: засобах масової інформації, бізнесі, особистому спілкуванні тощо. Особливо важливим це питання є у контексті політики, оскільки саме вона відповідає за функціонування держави та всіх іiї галузей.

Якщо говорити про політичні тексти, то найбільш маніпулятивно спрямованими є промови, 
позаяк готуються вони завчасно, а отже, там присутні виважені прийоми впливу. Також вони відрізняються своєю орієнтованістю на аудиторію, оратори мають чітку мету виголошення промови: агітація, пропаганда, опозиція «корисно-шкідливо» і т.п. [1, с. 45]. Ще однією перевагою промов для впливу на свідомість адресата є прямий контакт, оскільки дуже часто вони виголошуються напряму перед народом.

Як стверджує О.В. Падалка, політичні промови належать до групи інформативно-персуазивних текстів [2, с. 66]. Ми поділяємо іiі думку і вважаємо, що цей тип тексту є інформативним, оскільки виголошення промови супроводжується наданням аудиторії певної інформації 3 того чи іншого приводу. При цьому політичні промови вважаються також персуазивними, позаяк, за визначенням В.С. Чернявської, персуазивність трактується як вплив оратора на його адресата 3 метою переконати його в чомусь, спонукати адресата до скоєння або нескоєння ним певних дій [3, с. 25-26]. Задля реалізації цього ефекту автори текстів вдаються до різноманітних методів, одним iз яких є метафора, що спостерігається у кожному тексті політичного виступу і відповідно називається політичною.

За словами М. Едельмана, метафора у політиці пробуджує приховані тенденції та імпульси у громадських масах [4]. Тобто вона слугує елементом спонукання реципієнтів до певних дій.

Безперечним фактом у наш час $\epsilon$ те, що сучасний політичний дискурс є глибоко метафоризованим. Політична метафора є одним із найсильніших засобів, за допомогою яких політики намагаються впливати на масову свідомість аудиторії [5, с. 119]. Вважаємо, що метафора у політичних промовах $\epsilon$ досить виразним засобом акцентування, а тому i привернення уваги, оскільки цей троп уводить у текст поняття, віддалені від політичного світу, задля ілюстрації того чи іншого предмета/явища шляхом їхнього зіставлення. Отже, зважаючи на наміри автора, метафора може викликати у свідомості аудиторії різні картини реальності, що й робить цей художній засіб у наведеному дискурсі політичним елементом впливу.

Досліджуючи у роботі вплив політичної метафори, видається доцільним розглянути класифікацію об’єкта наукової розвідки. За типологією В.В. Петренка виокремлюють метафори за концептосферами із життя людини - будинок, механізм, організм, сім'я та родинні стосунки, надприродна істота, театр, спортивні змагання, шлях i засоби пересування, війна, рослина, природна стихія, кухня та їжа [6, с. 118].

Отже, важливим аспектом нашої роботи є аналіз використаних тропів у промовах політиків на предмет наявності у них маніпулятивного впливу.
Стверджуємо, що метафору необхідно розглядати не лише як один із методів прикрашання текстів, а й як один із потужних засобів впливу на свідомість аудиторії. Середньостатистичний слухач, на якого й орієнтована більшість промов політиків, не в змозі побачити прихований сенс використання згаданого художнього засобу, оскільки найчастіше він сприймається як показник красномовства оратора.

Мета статті - розкрити маніпулятивну спрямованість використання політичної метафори у промовах сучасних французьких політиків.

Виклад основного матеріалу дослідження. Аналізуючи промови сучасних французьких політиків, таких як Емманюель Макрон, Франсуа Олланд та Жан Кастекс, ми помітили, що кожна 3 їхніх промов не обходиться без використання метафор. Вони своєю чергою мають різну мету використання. Деякі 3 них слугують прикрасою тексту, а от інші мають приховану ціль - вплинути на адресата. Розглянемо конкретні приклади.

Tous nous ont dit que malgré nos efforts pour le freiner, le virus continue de se propager et est en train de s'accélérer (1).

У поданому уривку використовується метафора шляху та засобів пересування, позаяк вірус порівнюється з транспортом, який набирає обертів - s'accélérer (укр. прискорювати свій рух) (тут і далі переклад наш - Б.Ж., А.C.), та який не можна зупинити - freiner (укр. знижувати швидкість, гальмувати). Ототожнювання COVID-19 3 транспортним засобом має на меті зображення його руйнівної дії, оскільки, якщо автомобіль несеться 3 великою швидкістю, він може завдати шкоди людям та навколишньому середовищу так само, як і вірус. Отже, маніпулятивна ціль оратора - створити образ нищівного об'єкта, який насувається на країну, для того, щоб надати серйозного значення його появі.

C'est aussi de se préparer à une possible deuxième vague qui touchera un peu plus tard...(1).

У цьому прикладі ми бачимо, що наплив захворювань порівнюється 3 хвилею, яка накочується на берег. Таке ототожнення вже давно увійшло в обіг і часто використовується стосовно всіляких негараздів (хвиля обурення, вибухова хвиля, хвиля гніву і т.п.). Це дає змогу уявити вірус як природну стихію, яка несеться на людей, що своєю чергою не передвіщає нічого хорошого, позаяк вона зносить усе на своєму шляху. Саме так презентує Емманюель Макрон у своїй промові COVID-19.

Середньостатистичний слухач уже давно звик до такого використання метафори, але, проаналізувавши iii використання, можемо констатувати, що художній засіб у промові президента має на меті демонізувати коронавірусну хворобу. 
Він висловлює в такий спосіб свої побоювання стосовно захворювання та передає такі настрої своїй аудиторії. У цьому реченні підтверджується його бажання надати серйозного значення вказаній події.

Je dois le dire, seule l'extraordinaire force du peuple libanais a permis au pays exsangue, épuisé, en colère, de préserver depuis ce qui pouvait encore l'être (2).

У поданому уривку Ліван порівнюється 3 живим організмом, що $є$ відповідно прикладом метафори організму. Описуючи ситуацію у країні, для виступу політика було підібрано такі вирази, як «безкровний, виснажений, злий» (фр. exsangue, épuisé, en colère), що зображує Ліван $з$ рисами живої істоти. Таке експресивне порівняння впливає на сприйняття аудиторією змісту промови, оскільки у свідомості виникає перебільшена картина реальності. У такий спосіб Емманюель Макрон привернув увагу суспільства до проблем країни. Він маніпулював зображенням дійсності для того, щоб афішувати серйозність проблеми.

Cette force et cette amitié indéfectible ont été prises en otage par une classe politique soumise au jeu mortifère de la corruption et de la terreu (2).

Словосполучення prendre en otages (укр. брати в заручники) є відображенням метафори війни, позаяк за словником цей вираз має таке значення:

1. Expression signifiant qu'une personne est retenue contre son gré dans un endroit. Sa libération se fera sous conditions [7].

Відзначаємо, що у контексті вибраної промови цей зворот має переносне значення, оскільки його дія відображається на неживому предметі, а саме на «силі та непохитній дружбі» (фр. cette force et cette amitié indéfectible ont été prises en otage). Оратор використовує проаналізований елемент кримінального значення для того, щоб обчорнити дії представників ліванської влади. Такий зворот $\epsilon$, безумовно, способом маніпуляції емоціями адресата, позаяк у реченні присутні антонімічні поняття «дружба» (фр. amitié) - позитивний вплив та «взяття у заручники» (фр. prise d'otage) -негативний вплив. Це відображається на сприйняті аудиторією понять «хороше-погане»: політики, які зневажили дружбу, стають об'єктом неприязні - прагматична ціль адресанта досягнута.

Nous avons vu tous les jeux se faire. Les institutions ne peuvent être les spectateurs passifs de ce qui se passe aujourd'hui (2).

У промові Емманюеля Макрона нам зустрілася метафора театру, яка була виражена словосполученням être les spectateurs passifs (укр. бути пасивними глядачами/спостерігачами). У цьому прикладі оратор проводить паралель між глядачем у театрі та політиком, спираючись на той факт, що двоє не беруть участі у подіях, що відбуваються, а лише спостерігають за ситуацією. Така репутація не $є$ прийнятною для влади, оскільки вона має бути активною ланкою творення змін у країні. Це налаштовує слухачів на сприйняття образу ліванського політика як негативного.

Отже, у цьому прикладі також відзначаємо маніпулятивний аспект, за яким адресант викликає у аудиторії бажані відчуття та емоції, впевнено жонглюючи порівняннями.

...dans la gestion de cette crise, les élus ont été remarquables d'implication et de dévouement, à commencer par les maires qui ont, comme toujours, été combattants de la première ligne et de la première heure (3).

Яскравим прикладом метафори війни є вислів les maires ont, comme toujours, été combattants de la première ligne et de la première heure (укр. мери, як завжди, були бійцями на передовій із самої першої години).

Показовим словом виразу є іменник combattant (укр. боєць, фронтовик), який у цьому контексті використовується стосовно політиків, а саме мерів. Таке порівняння ідеалізує останніх, демонструє героїчність їхніх дій, позаяк воїни на фронті, на передовій, безперечно, є героями, які рятують життя інших, цілих народів та країн. Тобто тут іде гра на асоціацію. За допомогою такого прийому можна маніпулювати поняттями «хороше-погане».

Celui [État d'exclusion] qui d'ailleurs, prôné par les mêmes, démantèle la protection sociale, réduit les services publics... (4).

Об'єктом нашого аналізу стає метафора будинку, виражена дієсловом démanteler (укр. зносити, демонтувати, руйнувати):

1. Démolir les fortications, détruire un édifice.

2. (figuré) Détruire l'organisation d'un réseau, l'anéantir [7].

У контексті промови програму соціальної захищеності громадян (la protection sociale) було порівняно з будинком, який може зруйнуватися під впливом держави відчуження (État d'exclusion). Демонструючи своє бачення проблеми, Франсуа Олланд використав художній засіб з метою експресивізації висловлення. Порівняємо 2 варіанти:

1. La protection sociale sera inaccessible (укр. програма соціальної захищеності громадян стане недоступною).

2. La protection sociale sera démantelée (укр. програма соціальної захищеності громадян буде ліквідована/знищена).

Вибрана метафора неодмінно впливає на бачення реальності слухачами, вони сприймають iіi відповідно до того, як було подано інформацію. Зважаючи на той факт, що прикметник «знищений» $є$ більш емоціональним, ніж прикметник «недоступний», у свідомості адресатів виникає яскравіша реакція на слова мовця. 
...elle (la cohésion) exige de la mesure pour se garder de la provocation qui attise et de la stigmatisation qui blesse (4).

Представлений вище художній засіб відносимо до групи метафор організму. Нам вдалося зробити такий висновок завдяки звороту la stigmatisation qui blesse (укр. стигматизація, яка ранить/завдає болю), у якому ключовим словом конструкції виступає дієслово blesser.

Говорячи про тероризм, спікер порівнює стигматизацію з об' єктом або навіть людиною, що завдає шкоди живій особі, яка у нашому контексті є народом Франції. Стверджуємо, що таке використання тропу пов'язане з бажанням автора надати висловленню більш емоційного значення, позаяк аналізований фрагмент 3 метафорою має експресивне забарвлення.

Усім людям знайоме відчуття болю, фізичного та емоційного, тому порівняння, основане на апперцептивному сприйнятті, є дуже результативним у плані отримання реакції аудиторії. Розглянемо термін «апперцепція», який за словником визначається як зумовленість сприйняття людиною тих чи інших предметів або явищ об'єктивного світу іiі попереднім досвідом та психічним станом у момент сприйняття; сприймання залежить не тільки від об'єкта, а й від суб'єкта, від наявних у нього потреб, інтересів, уявлень, понять тощо; безпосередні враження від об'єкта активізують певні сліди минулих вражень; вони включаються у склад попереднього досвіду, завдяки чому сприймання відбувається швидше, набуває вибірковості й осмисленості [8].

Констатуємо, що людина сприймає подану інформацію відповідно до своїх життєвих знань. Якщо до політики середньостатистична людина відношення не має, то проблеми, пов'язані з фізіологією, ій знайомі. Завдяки цьому спосіб презентації політичних явищ через призму людського досвіду $є$ досить ефективним, позаяк аудиторія буде сприймати таку інформацію дуже особисто, $\mathrm{i}$ реакція на неї буде відповідною.

Висновки. Отже, виявлено, що серед методів впливу політичних текстів виокремлюють метафору, яку відповідно називають політичною. Наведе поняття трактуємо як художній засіб, заснований на прихованому порівнянні реалій політичного світу 3 елементами інших суспільних сфер.

Проаналізований матеріал дає змогу стверджувати, що метафора може бути не лише елементом прикрашання тексту та показником красномовства оратора, а здатна впливати на свідомість адресата. Нами було виокремлено основні маніпулятивні спрямованості цього тропу.

По-перше, метафору можна розглядати як засіб впливу на реципієнта через створення у його свідомості бажаних картин реальності. Іншими словами, використовуючи метафору, адресант порівнює подану інформацію з іншими реаліями різних сфер нашого життя. У результаті, вміло жонглюючи образами, можна надати серйозності тому чи іншому явищу, демонізувати або ідеалізувати будьяку ситуацію або людину. Таке приховане порівняння є важливим методом підміни дійсності.

По-друге, це засіб експресивізації висловлення. У такий спосіб політик отримує яскравішу реакцію своєї аудиторії на адресоване повідомлення, привертає їхню увагу. Він досягає появи бажаних емоцій та почуттів, а отже, може керувати результатом виголошення промови.

По-третє, можемо виокремити також ефект унаочнення події або явища, про які йдеться. Порівняння політичних реалій 3 об'єктами повсякденного життя людини допомагає останній краще осягнути інформацію, яку транслює оратор, а також додає прихильності політику, який тямить у красномовстві та орієнтується на середньостатистичного слухача.

Отримані результати свідчать про те, що метафора має розглядатися крізь призму маніпуляції, a не лише як один із тропів поетичного мовлення. Головним чином, вона розкриває свій потенціал у політичних текстах, метою яких є, зокрема, вплив на аудиторію.

Перспективи дослідження полягають у розширенні знань про маніпулятивну спрямованість метафоричних конструкцій не тільки у політичному дискурсі, але у інших сферах мовлення, наприклад у засобах масової інформації, які також $\epsilon$ серйозним важелем у формуванні світогляду.

\section{ЛITЕРАТУРА}

1. Canetti E. Masse und Macht. Hamburg : Claassen, 1960. 342 p.

2. Падалка О.В. Політична промова та ії просодичні характеристики. Науковий вісник Східноєвропейського національного університету імені Лесі Українки. Філологічні науки. Мовознавство. 2012. № 6 (231). С. 66-69.

3. Чернявская В.Е. Дискурс власти и власть дискурса: проблемы речевого воздействия. Москва : Флинта : Наука, 2006. 134 с.

4. Edelman M. Politics as Symbolic Action: Mass Arousal and Quiescence. Chicago : Markham, 1971. 198 p.

5. Погребняк Н.В. Воздействующий потенциал метафоры в современном политическом медиадискурсе. Известия Волгоградского государственного педагогического университета. Языкознание и литературоведение. Волгоград, 2019. № 10 (143). С. 118-125.

6. Петренко В.В. Політична мова : навчальний посібник. Київ : IMB, 2006. 215 с. 
7. Linternaute. URL: https://www.linternaute.com (дата звернення: 20.10.2020).

8. Тлумачення: апперцепція. URL: https://slovnyk.ua/index.php?swrd=апперцепція (дата звернення: 20.10.2020).

\section{ДЖЕРЕЛА ІЛЮСТРАТИВНОГО МАТЕРІАЛУ}

1. Déclaration de M. Emmanuel Macron, président de la République, sur l'épidémie de COViD-19. URL: https://www.vie-publique.fr/discours/273869-emmanuel-macron-12032020-coronavirus (дата звернення: 18.10.2020).

2. Conférence de presse de M. Emmanuel Macron, président de la République, sur la situation au Liban. URL: https://www.vie-publique.fr/discours/276559-emmanuel-macron-27092020-liban (дата звернення: 18.10.2020).

3. Déclaration de politique générale de M. Jean Castex, Premier ministre, sur la crise économique et sanitaire, la France des territoires, le soutien à l'activité, le système de santé, les retraites et l'ordre républicain, au Sénat le 16 juillet 2020. URL: https://www.vie-publique.fr/discours/275476-jean-castex-16072020declaration-politique-generale-castex-au-senat (дата звернення: 18.10.2020).

4. La démocratie face au terrorisme, Paris 8 septembre 2016 Discours de François Hollande, Président de la République. URL: https://jean-jaures.org/sites/default/files/redac/commun/discoursfrancoishollande.pdf (дата звернення: 18.10.2020).

\section{REFERENCES}

1. Canetti, E. (1960). Masse und Macht. Hamburg: Claassen.

2. Padalka, O.V. (2012). Politychna promova ta yiyi prosodychni kharakterystyky [Political speech and its prosodic characteristics]. Naukovyy visnyk Skhidnoyevropeys 'koho natsional'noho universytetu imeni Lesi Ukrayinky. Filolohichni nauky. Movoznavstvo - Scientific Bulletin of the Lesia Ukrainka East European National University. Philological sciences. Linguistics. Vol. 6. P. 66-69.

3. Chernyavskaya, V.Ye. (2006). Diskurs vlasti i vlast' diskursa: problemy rechevogo vozdeystviya [Discourse of power and the power of discourse: problems of speech impact]. Moscow: Flinta: Nauka.

4. Edelman, M. (1971). Politics as Symbolic Action: Mass Arousal and Quiescence. Chicago: Markham.

5. Pogrebnyak, N.V. (2019). Vozdeystvuyushchiy potentsial metafory v sovremennom politicheskom mediadiskurse [The impacting potential of metaphor in modern political media discourse]. Izvestiya Volgogradskogo gosudarstvennogo pedagogicheskogo universiteta. Yazykoznaniye i literaturovedeniye Bulletin of the Volgograd State Pedagogical University. Linguistics and Literary Studies. Vol. 10 (143). P. $118-125$.

6. Petrenko, V.V. (2006). Politychna mova: navchalnyi posibnyk [Political language: a textbook]. Kyiv : IMV.

7. Linternaute. Retrieved from: https://www.linternaute.com.

8. Tlumachennya: appertseptsiya [Interpretation: apperception]. URL: https://slovnyk.ua/index.php? swrd=апперцепція. 